\title{
Penerapan Pendekatan Realistic Mathematics Education Dalam Pembelajaran Matematika Materi PersamaAn Garis LURUS DI SMP KRISTEN TOMOHON
}

\author{
Derel Filandy Kaunang \\ Program Studi Pendidikan Matematika, FMIPA, Universitas Negeri Manado \\ Jl Tondano, Koya, Tondano Selatan, Manado, Sulawesi Utara, 95618, Indonesia \\ derelkaunang@unima.ac.id
}

\begin{abstract}
Abstrak
Penelitian ini dilaksanakan dengan tujuan untuk mengetahui perbedaan hasil belajar siswa yang diajarkan dengan pendekatan Realistic Mathematics Education (RME) dan siswa yang diajarkan dengan pembelajaran langsung pada materi persamaan garis lurus di kelas VIII SMP. Penelitian ini menggunakan metode true experimental. Populasi yang diambil adalah seluruh siswa kelas VIII SMP Kristen Tomohon yang terdiri dari enam kelas sedangkan sampel yang diambil secara acak adalah dua kelas yang homogen yaitu kelas VIIIA sebagai kelas eksperimen dan kelas VIIIB sebagai kelas kontrol. Kelas eksperimen terdiri dari 24 orang siswa dan kelas kontrol terdiri dari 24 orang siswa. Penelitian ini merupakan model rancangan Pretest-Posttest Control Group Design. Data diambil dan dikumpulkan dari tes hasil belajar siswa. Data dalam penelitian ini adalah selisih hasil belajar siswa yang diperoleh dari skor pretes dan posttest pada materi persamaan garis lurus. Berdasarkan analisis data dengan uji t diperolah bahwa $t_{\text {hitung }}=2,824>$ $t_{\text {tabel }}=2,013$ untuk $\alpha=0,05$. Berdasarkan hasil penelitian maka dapat diambil kesimpulan bahwa rata-rata hasil belajar siswa yang diajarkan dengan pendekatan Realistic Mathematics Education (RME) lebih tinggi dari rata-rata hasil belajar siswa yang diajarkan dengan dengan pembelajaran langsung.

Kata Kunci : Realistic Mathematics Education, Pembelajaran Matematika, Persamaan Garis Lurus
\end{abstract}

\begin{abstract}
The aim of this research is to investigate the difference between students' learning outcomes taught by Realistic Mathematics Education (RME) approach and the students taught by direct learning on the equation of straight line in class VIII SMP. This research is used true experimental method. The population is all students of class VIII SMP Kristen Tomohon consists of six classes while the the random samples are two homogeneous classes which are class VIIIA as an experiment class and class VIIIB as a control class. The experimental class consists of 24 students and the control class consists of 24 students. This research is a design model of Pretest-Posttest Control Group Design. The data are gathered and collected from students' learning outcomes. The data in this research are the differences of the students' learning result obtained from the pretest and posttest scores on the equation of straight line equation. Furthermore, the data analysis with $t$ test is $t_{\text {count }}=2,824>t_{\text {table }}=2.013$ for $\alpha=0,05$. Based on the result of this research, it can be concluded that the average of student learning outcomes taught with Realistic Mathematics Education (RME) approach is higher than the average of student learning outcomes taught with direct learning.

Keywords: Realistic Mathematics Education, Mathematics Learning, Equation of Straight Line
\end{abstract}




\section{Pendahuluan}

Matematika merupakan salah satu ilmu dasar yang mempunyai peranan penting dalam upaya penguasaan ilmu pengetahuan dan teknologi. Banyak persoalan di sekitar matematika dan pembelajaran matematika, tapi tidak dapat disangkal bahwa matematika mempunyai peranan yang cukup besar dalam memberikan berbagai kemampuan kepada siswa untuk keperluan penataan kemampuan berpikir dan kemampuan memecahkan masalah dalam kehidupan sehari-hari. Hal ini sesuai dengan tujuan pendidikan matematika, yaitu (1) tujuan yang bersifat formal, menekankan pada penataan nalar serta pembentukan kepribadian, dan (2) tujuan yang bersifat material, menekankan pada penerapan matematika dan keterampilan matematika (Soedjadi, 2000).

Kenyataan ini menunjukkan bahwa pencapaian tujuan pembelajaran matematika, masih belum memenuhi harapan. Hal ini diduga disebabkan sifat abstrak yang terdapat pada matematika.

Diduga pula karena selama ini siswa hanya cenderung diajar untuk menghafal konsep atau prinsip matematika, tanpa disertai pemahaman yang baik. Pembelajaran yang selama ini mendominasi kelas-kelas matematika di Indonesia umumnya berbasis pada behaviorisme dengan penekanan pada transfer pengetahuan dan latihan. Guru mendominasi kelas dan berfungsi sebagai sumber belajar utama. Guru menyajikan pengetahuan matematika kepada siswa, siswa memperhatikan penjelasan dan contoh yang diberikan oleh guru, kemudian siswa menyelesaikan soal-soal sejenis yang diberikan guru (Banjarnahor, 2011). Pembelajaran semacam ini kurang memperhatikan aktivitas aktif siswa, interaksi siswa, dan pengkonstruksian pengetahuan oleh siswa. Aktivitas aktif siswa yang dimaksudkan di sini tidak hanya sekedar menyelesaikan soal-soal sesuai contoh yang diberikan guru, tetapi perlu pula melibatkan berbagai aktivitas aktif yang dapat merangsang kemampuan berpikir dan kemampuan memecahkan masalah yang merupakan tujuan pembelajaran matematika. Pembelajaran matematika dewasa ini harus lebih menekankan kebermaknaan dari pada proses indoktrinasi konsep. Matematika harus diajarkan melalui permasalahan nyata yang dekat dengan siswa (Mangelep, 2017).

Berdasarkan hasil observasi peneliti di kelas VIII SMP Kristen Tomohon, kondisi pembelajaran seperti yang digambarkan diatas masih sering terjadi. Siswa masih kurang aktif dalam proses belajar mengajar, hal ini mengakibatkan hasil belajar matematika siswa tergolong rendah.

Kondisi hasil belajar siswa yang memprihatinkan tersebut harus terus diupayakan untuk diperbaiki. Upaya tersebut dapat dilakukan di antaranya melalui perbaikan kegiatan pembelajaran. Kegiatan pembelajaran merupakan faktor penting yang perlu mendapat perhatian. Kegiatan pembelajaran yang berpusat 
pada guru sudah saatnya diganti menjadi berpusat pada siswa (Soedjadi, 2000). mengatakan bahwa proses pembelajaran matematika perlu lebih menekankan pada keterlibatan secara optimal para peserta didik secara sadar. Kurikulum 2013 menghendaki keaktifan siswa dalam belajar. Hal ini sejalan dengan Salinan Lampiran Permendikbud No. 65 tahun 2013 tentang Standar Kompetensi Lulusan dan Standar Isi maka salah satu prinsip pembelajaran yang digunakan yaitu, dari peserta didik diberi tahu menuju peserta didik mencari tahu.

Strategi pembelajaran aktif ditandai dengan optimalisasi interaksi antar semua elemen pembelajaran (guru, siswa, media). Strategi ini menekankan peran siswa yang aktif membangun sendiri pengetahuannya yang dipelajari dalam pembelajaran.

Peranan guru lebih bersifat fasilitator dan memiliki kewajiban dalam upaya peningkatan kualitas pembelajaran. Oleh karena itu, guru dituntut untuk selalu berinovasi dalam melaksanakan proses pembelajaran. Inovasi guru tersebut misalnya dalam hal pemilihan pendekatan pembelajaran.

Realistic Mathematics Education (RME) merupakan salah satu pendekatan dalam pembelajaran matematika. RME yang telah dikembangkan di Nederland sejak tahun 1970 (van den Heuvel-Panhuizen, 1999), menggabungkan pandangan tentang apa itu matematika, bagaimana siswa belajar matematika, dan bagaimana mengajarkan matematika. RME adalah suatu pembelajaran yang sejalan dengan prinsip konstruktivis dan merupakan pendekatan pembelajaran yang berfokus pada aktivitas siswa dalam mengkonstruksi pengetahuan. Pendekatan ini menuntut keaktifan siswa dalam proses belajar.

RME memiliki lima karakteristik (Gravemeijer, 1994) yang merupakan operasionalisasi dari prinsip-prinsip RME. Berikut uraian kelima karakteristik tersebut.

(1) Menggunakan masalah konstekstual (the use of contexts). Pembelajaran diawali dengan menggunakan masalah kontekstual, tidak dimulai dari sistem formal. Masalah kontekstual yang diangkat sebagai topik awal pembelajaran harus merupakan masalah sederhana yang dikenali oleh siswa.

(2) Menggunakan model (use of models, bridging by vertical instruments). Pada pembelajaran dengan pendekatan RME, digunakan model yang dikembangkan sendiri oleh siswa dari situasi yang sebenarnya (model of). Model tersebut digunakan sebagai jembatan antara level pemahaman yang satu ke level pemahaman yang lain. Selanjutnya, model ini diarahkan untuk menjadi model ke arah matematika formal (model for).

(3) Menggunakan kontribusi siswa (students contribution). Kontribusi yang besar pada proses pembelajaran datang dari siswa, artinya semua pikiran (konstruksi dan produksi) siswa diperhatikan. Kontribusi dapat berupa aneka jawaban, aneka cara, atau aneka pendapat siswa. 
(4) Interaktivitas (interactivity) yang dikonstruksi dan dikembangkan Mengoptimalkan proses pembelajaran melalui interaksi siswa dengan siswa, siswa dengan guru, dan siswa dengan sarana prasarana merupakan hal yang penting dalam RME. Negosiasi, diskusi, dan kerjasama adalah elemen-elemen penting dalam RME. Metode informal yang dikembangkan siswa digunakan sebagai acuan menuju metode formal. Dalam hal ini, siswa dilibatkan dalam menjelaskan, membenarkan, menyatakan kesetujuan atau ketidaksetujuan, menanyakan alternatif, dan melakukan refleksi. Interaksi terus dioptimalkan sampai konstruksi yang diinginkan diperoleh, sehingga interaksi tersebut bermanfaat.

(5) Keterkaitan dengan topik lainnya (intertwining). Struktur dan konsep matematika saling berkaitan. Oleh karena itu, keterkaitan dan keterintegrasian antar topik (unit pelajaran) harus dieksplorasi untuk mendukung terjadinya proses pembelajaran yang lebih bermakna. Intertwin dapat terlihat melalui masalah kontekstual yang diberikan.

Selanjutnya, menurut Suwarsono (2001), terdapat beberapa kekuatan atau kelebihan dari RME, antara lain: (1) RME memberikan pengertian yang jelas dan operasional kepada siswa tentang keterkaitan antara matematika dengan kehidupan sehari-hari (kehidupan dunia nyata) dan tentang kegunaan matematika pada umumnya bagi manusia. (2) RME memberikan pengertian yang jelas dan operasional kepada siswa bahwa matematika adalah suatu bidang kajian sendiri oleh siswa dan setiap orang 'biasa' yang lain, tidak hanya oleh mereka yang disebut pakar dalam bidang tersebut. (3) RME memberikan pengertian yang jelas dan operasional kepada siswa bahwa cara penyelesaian suatu soal atau masalah tidak harus tunggal, dan tidak harus sama antara orang yang satu dengan orang yang lain. Setiap orang bisa menemukan atau menggunakan cara sendiri, asalkan orang itu bersungguh-sungguh dalam mengerjakan soal atau masalah tersebut. Selanjutnya dengan membandingkan cara penyelesaian yang satu dengan cara penyelesaian yang lain, akan bisa diperoleh cara penyelesaian yang paling tepat, sesuai dengan tujuan dari proses penyelesaian soal atau masalah tersebut. (4) RME memberikan pengertian yang jelas dan operasional kepada siswa bahwa dalam mempelajari matematika, proses pembelajaran merupakan sesuatu yang utama, dan untuk mempelajari matematika orang harus menjalani proses itu dan berusaha untuk menemukan sendiri konsep-konsep matematika, dengan bantuan pihak lain yang sudah lebih tahu (misalnya guru). Tanpa kemauan untuk menjalani sendiri proses tersebut, pembelajaran yang bermakna tidak akan terjadi.

Dengan RME, siswa mempelajari ide-ide dan konsep-konsep matematika melalui permasalahan kontekstual yang berkaitan dengan lingkungan siswa tersebut. Selanjutnya, secara bertahap siswa dibimbing untuk menguasai konsep- 


\section{konsep matematika. Penerapan RME} memberikan harapan untuk meningkatkan prestasi belajar matematika siswa.

Berdasarkan uraian di atas, diharapkan RME dapat menjadi alternatif pendekatan pembelajaran yang baik. Selanjutnya, hal ini membuat peneliti tertarik untuk menerapkan RME dan membandingkannya dengan pembelajaran pembelajaran langsung. Pada penelitian ini dipilih materi persamaan garis lurus berdasarkan hasil diskusi peneliti dengan guru yang ada di sekolah pada saat observasi.

\section{Metode}

Metode penelitian yang digunakan dalam adalah metode true experimental. Populasi dalam penelitian ini adalah siswa kelas VIII SMP Kristen Tomohon tahun ajaran 2016/2017 yang terdiri dari 6 kelas yaitu kelas VIII-A, VIII-B, VIII-C, VIII-D, VIII-E, dan VIII-F. Sampel penelitian diambil dua kelas secara undian yaitu kelas VIII-A sebagai kelas eksperimen dan kelas VIII-B sebagai kelas kontrol. Hasil belajar dalam penelitian ini adalah selisih skor pretest dan posttest.

Penelitian ini menggunakan rancangan penelitian pretest-posttest control grup design yang digambarkan dalam bentuk tabel sebagai berikut :

Tabel 1.

Rancangan Penelitian

\begin{tabular}{cccc|}
\hline Kelas & Pretest & Treatment & Posttest \\
\hline Eksperimen & $\mathrm{O}_{1}$ & $\mathrm{X}$ & $\mathrm{O}_{2}$ \\
\hline Kontrol & $\mathrm{O}_{3}$ & & $\mathrm{O}_{4}$ \\
\hline
\end{tabular}

(Sugiyono, 2009)
Keterangan :

$X$ : Perlakuan terhadap kelas Eksperimen

$\mathrm{O}_{1}$ : Kelompok Kontrol

$\mathrm{O}_{2}$ : Tes Awal Kelompok Eksperimen

$\mathrm{O}_{3}$ : Tes Awal Kelompok Kontrol

Instrumen dalam penelitian ini adalah tes hasil belajar dalam bentuk essay tes. Berikut salah satu soal tes hasil belajar beserta respon siswa pada kelompok eksperimen dan kontrol.

Sebuah pesawat terbang akan mendarat di bandara. Mulai roda keluar ( 0 detik) hingga mendarat, pesawat tersebut membentuk garis lurus dengan kemiringan (gradien) -3 . Pada saat 2 detik sesudah roda dikeluarkan, pesawat tersebut berada pada ketinggian $700 \mathrm{~m}$ dari atas tanah.

. Tulislah persamaan garis yang menunjukkan hubungan antara waktu dan ketinggian pesawat.

b. Berapakah ketinggian pesawat di atas tanah, pada saat 8 detik sesudah roda keluar?

Gambar 1. Salah Satu Soal Tes Hasil Belajar dan Penyelesaian Siswa

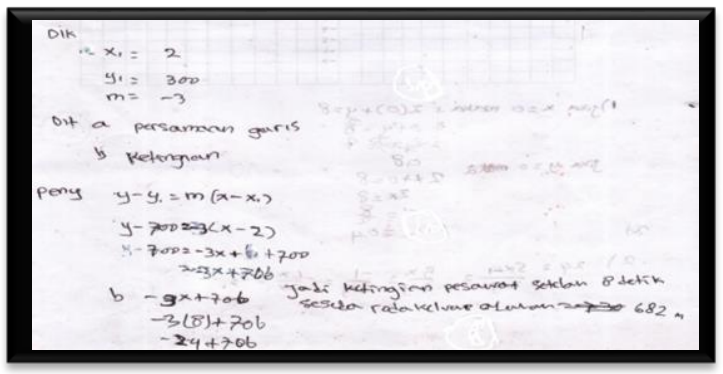

Gambar 2. Penyelesaian Siswa Kelas Eksperimen

Dile : Pescowat membentuk gari's lur us demagn kemiringan (gadien) $=-3$ Pada Saat 2detik Sesudeh roda diketwarkan, Pesawat berada Pada ketringolian $700 \mathrm{~m}$ dari atas tanah.

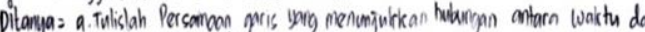
kethminan Pesaluat?

b. berspankah ketingginan Possuart diatas tanch, Pada Soat 8 detik sesudal roda keluar?

Penvelecsian: $a .700 \mathrm{~m}: 2$ detik

$=\underline{550}$

b. $8 \times 350=2800 \mathrm{~m}$

Jadi, ketinguian Pescout diatas tanah adalah $2800 \mathrm{~m}$

Gambar 3. Penyelesaian Siswa Kelas Kontrol 
Sebelum instrumen hasil belajar ini digunakan terlebih dahulu akan dilakukan uji Validitas dan Reliabilitas. Validitas yang akan digunakan dalam tes ini adalah validitas isi. Salah satu cara untuk memmperoleh validitas isi adalah dengan melihat kisi-kisi soal yang membentuk tes itu. Jika keseluruhan soal nampak mengukur apa yang seharusnya tes itu digunakan, tidak diragukan lagi bahwa validitas isi sudah terpenuhi. Uji reliabilitasnya menggunakan rumus Alfa cronbach.

$$
r_{11}=\left(\frac{n}{n-1}\right)\left(1-\frac{\Sigma \sigma_{i}^{2}}{\sigma_{t}^{2}}\right)
$$

Keterangan:

$$
\begin{array}{ll}
r_{11} & =\text { reliabilitas variabel } \\
\mathrm{n} & =\text { banyaknya item soal } \\
\Sigma \sigma_{i}{ }^{2} & =\text { jumlah varians butir soal } \\
S_{\sigma}{ }^{2} & =\text { varians total }
\end{array}
$$

(Arikunto, 2010)

Teknik pengumpulan data dalam penelitian ini diperoleh dengan cara memberikan tes kepada siswa. Untuk teknik analisis data dilakukan pengujian hipotesis dengan menggunakan uji-t. Namun terlebih dahulu dilakukan uji normalitas data dengan menggunakan software minitab dan uji homogenitas varians.

Data yang telah diperoleh dalam penelitian ini dianalisis dengan menggunakan uji perbedaan dua rata-rata dengan rumus sebagai berikut.

$$
t=\frac{\overline{X_{1}}-\overline{X_{2}}}{s \sqrt{\left[\frac{1}{n_{1}}+\frac{1}{n_{2}}\right]}}
$$

dengan varians sampel :

$$
S p^{2}=\frac{\left(n_{1}-1\right) S_{1}{ }^{2}+\left(n_{2}-1\right) S_{2}{ }^{2}}{n_{1}+n_{2}-2}
$$

(Sudjana, 2005)

Keterangan :

$\overline{X_{1}}=$ nilai rata-rata hasil belajar kelas eksperimen

$\overline{X_{2}}=$ nilai rata-rata hasil belajar kelas kontrol

$s$ = varians gabungan

$n_{1}=$ jumlah siswa kelas eksperimen

$n_{2}=$ jumlah siswa kelas kontrol

$S_{1}{ }^{2}=$ varians dari kelas eksperimen

$S_{2}{ }^{2}=$ varians dari kelas kontrol

Hipotesis statistik yang diuji adalah:

$H_{0}: \mu_{\mathrm{E}}=\mu_{\mathrm{K}}$

$\mathrm{H}_{1}: \mu_{\mathrm{E}}>\mu_{\mathrm{K}}$

Keterangan :

$\mu_{\mathrm{E}}=$ rata-rata hasil belajar kelas eksperimen

$\mu_{\mathrm{k}}=$ rata-rata hasil belajar kelas kontrol

\section{Hasil dan Pembahasan}

Hasil analisis data dari hasil tes awal dan tes akhir kelas eksperimen dan kelas kontrol dapat dilihat pada tabel berikut ini:

Tabel 2.

Ringkasan data hasil pretest dan posttest kelas eksperimen (kelas VIII )

\begin{tabular}{|clccc|}
\hline \multirow{2}{*}{ No } & \multirow{2}{*}{ Statistik } & \multicolumn{3}{c}{ Nilai Statistik } \\
\cline { 3 - 5 } & Pretest & Posttest & Selisih \\
\hline 1 & $\begin{array}{l}\text { Skor } \\
\text { maksimum }\end{array}$ & 27 & 97 & 84 \\
\hline 2 & $\begin{array}{l}\text { Skor } \\
\text { minimum }\end{array}$ & 10 & 49 & 34 \\
\hline 3 & Total skor & 409 & 1844 & 1435 \\
\hline 4 & Rata-rata & 17,042 & 76,833 & 59,792 \\
\hline 5 & $\begin{array}{l}\text { Standar } \\
\text { deviasi }\end{array}$ & 4,877 & 15,409 & 14,476 \\
\hline 6 & Varians & 23,781 & 237,449 & 209,563 \\
\hline
\end{tabular}


Tabel 3.

Ringkasan data hasil pretest dan posttest kelas kontrol (kelas VIIIB)

\begin{tabular}{|clccc|}
\hline \multirow{2}{*}{ No } & \multirow{2}{*}{ Statistik } & \multicolumn{3}{c}{ Nilai Statistik } \\
\cline { 3 - 5 } & & Pretest & Posttest & Selisih \\
\hline 1 & $\begin{array}{l}\text { Skor } \\
\text { maksimum }\end{array}$ & 27 & 92 & 69 \\
\hline 2 & $\begin{array}{l}\text { Skor } \\
\text { minimum }\end{array}$ & 12 & 47 & 30 \\
\hline 3 & Total skor & 467 & 1647 & 1180 \\
\hline 4 & Rata-rata & 19,458 & 68,625 & 49,167 \\
\hline 5 & $\begin{array}{l}\text { Standar } \\
\text { deviasi }\end{array}$ & 4,413 & 11,601 & 11,484 \\
\hline 6 & Varians & 19,476 & 134,592 & 131,884 \\
\hline
\end{tabular}

Dari hasil analisis di atas, diperoleh bahwa pada kelas eksperimen yang diajarkan dengan menggunakan pendekatan RME, menunjukkan adanya perbedaan terhadap hasil belajar siswa. Hal ini ditunjukkan rata-rata skor posttest dikurangi skor pretest pada kedua kelas. Untuk kelas eksperimen rata-rata skor posttest dikurangi skor pretest sebesar 59,792 lebih besar dari rata-rata skor posttest dikurangi skor pretest kelas kontrol yaitu sebesar 49,167. Setelah dianalisis dengan menggunakan uji t selisih dua rata-rata diperoleh $t_{\text {hitung }}=2,824>$ $t_{\text {tabel }}=2,013$.

Berdasarkan hasil analisis di atas menunjukkan bahwa terdapat perbedaan yang signifikan dari hasil belajar kedua kelas tersebut, dimana hasil belajar siswa yang diajarkan dengan menggunakan pendekatan Realistic Mathematics Education (RME) lebih tinggi dari hasil belajar siswa yang diajarkan dengan menggunakan pembelajaran langsung pada materi persamaan garis lurus.

RME pada dasarnya adalah pemanfaatan realitas dan lingkungan yang dipahami peserta didik untuk memperlancar proses pembelajaran matematika, sehingga mencapai tujuan pendidikan matematika yang lebih baik. Adapun tujuan dari pendidikan matematika adalah (1) Mempersiapkan siswa agar sanggup menghadapi perubahan keadaan dan pola piker dalam kehidupan dan dunia selalu berkembang, dan (2) Mempersiapkn siswa menggunakan matematika dan pola pikir matematika dalam kehidupan sehari dan dalam mempelajari berbagai ilmu pengetahuan.

Lebih lanjut yang dimaksud dengan realitas, yaitu hal-hal nyata atau konkret yang dapat diamati atau dipahami peserta didik lewat membayangkan, sedangkan yang dimaksud dengan lingkungan adalah lingkungan tempat peserta didik berada, baik lingkungan sekolah, keluarga maupun masyarakat yang dapat dipahami peserta didik. Lingkungan ini disebut lingkungan sehari-hari. Dengan pendekatan ini siswa tidak hanya mudah menguasai konsep dan materi pelajaran namun juga tidak cepat lupa dengan apa yang dipelajarinya.

Dari penjelasan tersebut dapat disimpulkan bahwa hasil penelitian eksperimen yang dilaksanakan di SMP Negeri 2 Tomohon dengan memberikan perlakuan menggunakan pendekatan Realistic Mathematic Education memberikan pengaruh terhadap hasil belajar siswa. Hal ini menunjukkan bahwa rata - rata hasil belajar siswa yang diajarkan dengan menggunakan pendekatan Realistic Mathematic 
Education (RME) lebih tinggi dari rata-rata hasil belajar siswa yang diajarkan dengan menggunakan pendekatan konvensional pokok bahasan persamaan garis lurus.

\section{Penutup}

Berdasarkan hasil penelitian dan pembahasan maka dapat disimpulkan bahwa rata-rata hasil belajar siswa yang diajarkan dengan menggunakan pendekatan Realistic Mathematics Education (RME) lebih tinggi dari rata-rata hasil belajar siswa yang diajarkan dengan menggunakan pembelajaran langsung materi persamaan garis lurus di kelas VIII SMP Kristen Tomohon.

\section{DAfTAR PUStaka}

Arikunto, S. (2010). Dasar-dasar Evaluasi Pendidikan. Bumi Aksara: Jakarta.

Gravemeijer, K. (1994). Developing Realistic Mathematics Education. Utrecht: Freudenthal Institute.

Banjarnahor, Humantal. (2011). Pembelajaran Matematika Realistik Dengan Setting Kooperatif. Jurnal Generasi Kampus Volume 4 No 1: 6885

Mangelep, (2017). Pengembangan Website Pembelajaran Matematika Realistik Untuk Siswa Sekolah Menengah Pertama. Mosharafa: Jurnal Pendidikan Matematika, Volume 6 No. 3: 431-439

Permendibud No. 65 Tahun 2013 Tentang

Standar Proses Pendidikan Dasar Dan Menengah.
Soedjadi, R. (2000). Kiat Pendidikan Matematika di Indonesia, (konstatasi keadaan masa kinimenuju harapan masa depan). Direktorat Jenderal Pendidikan Tinggi. Depdiknas.

Sudjana. (2005). Metode Statistika. Bandung: Tarsitos.

Sugiyono. (2009). Metode Penelitian Kuantitatif, Kualitatif dan R\&D. PT Alfabeta: Bandung.

Suwarsono, S. (2001). Beberapa Permasalahan yang Terkait dengan Upaya Implementasi Pendekatan Matematika Realistik di Indonesia. Makalah disajikan pada Seminar Nasional tentang Pendekatan Matematika Realistik di Universitas Sanata Dharma tanggal 14-15 November 2001.

Van den Heuvel-Panhuizen, M. (1999). Mathematics Education in the Netherlands: A Guide Tour. Freudenthal Institute Cd-rom for ICME9. Utrecht: Utrecht University.

\section{Riwayat Hidup PENULIS}

\section{Derel Filandy Kaunang, S.Pd., M.Pd.}

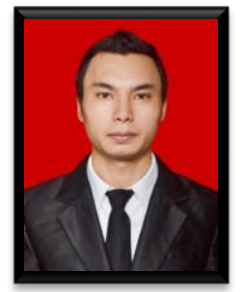

Lahir di Tomohon, tanggal 26 Januari 1990. Staf pengajar di Program Studi Pendidikan Matematika FMIPA Universitas Negeri Manado. Studi S1 Pendidikan Matematika di Universitas Negeri Manado, lulus tahun 2012; S2 Pendidikan Matematika di Universitas Negeri Surabaya, lulus tahun 2014. 